\title{
MENUNTASKAN HASIL BELAJAR MAHASISWA PRODI PENDIDIKAN KIMIA FKIP UNIVERSITAS RIAU DALAM MATA KULIAH KIMIA DASAR II MELALUI PEMBELAJARAN BERDASARKAN MASALAH TAHUN AKADEMIS 2011/2012
}

\author{
Rasmiwetti, Miharty, Rini \\ Program Studi Pendidikan Kimia MIPA FKIP UNRI Pekanbaru 28293 \\ Email : rasmiwetti.19@gmail.com
}

\begin{abstract}
Abstrak
Mata kuliah Kimia Dasar II merupakan pengulangan dan pengembangan dari kimia yang telah dipelajari mahasiswa di SMA. Oleh sebab itu diharapkan hasil belajar mahasiswa pada matakuliah Kimia Dasar II nilainya pada kategori tinggi. Hasil observasi dan wawancara dengan mahasiswa, diperoleh keterangan bahwa sebagian besar mahasiswa sulit untuk memahami materi. Untuk itu perlu dilakukan suatu usaha peningkatan kualitas pembelajaran agar hasil belajar mahasiswa lebih baik dan tuntas melalui penelitian tindakan kelas. Pada penelitian ini dilakukan pembelajaran dengan menerapkan pembelajaran berdasarkan masalah. Penelitian tindakan kelas ini bertujuan untuk meningkatkan dan menuntaskan kemampuan belajar mahasiswa Program studi Pendidikan Kimia FKIP Universitas Riau tahun akademis 2011/2012 dalam mata kuliah Kimia Dasar II. Penelitian dilaksanakan tiga siklus. Peningkatan ketuntasan hasil belajar mahasiswa dari Siklus I dengan Siklus II sebanyak 25\% dan dari Siklus II dengan Siklus III sebanyak 54,17\%. Peningkatan kemampuan belajar mahasiswa ini dengan cara: 1) Pengajaran dilaksanakan secara kelompok yang terdiri dari 5 atau 6 orang 2) Menggunakan media pembelajaran yang berupa buku bacaan, bahan pembelajaran yang sesuai dengan materi pembelajaran dan Lembaran Kerja Mahasiswa (LKM). 3) Dosen mendorong keaktifan mahasiswa waktu kegiatan kelompok. 4) Dosen memberikan arahan secara kelompok maupun secara klasikal. 5) Waktu untuk diskusi klasikal relatif lama.
\end{abstract}

Kata Kunci : Kimia Dasar II, Pembelajaran berdasarkan masalah, Ketuntasan belajar.

\begin{abstract}
Basic Chemistry II course is a repetition and development of chemistry which have been learned by students in high school. Therefore, the learning outcomes of student at the course Basic Chemistry II was expected in the high category. Through observations and interviews with students was obtained information that most of the students was difficult to understand about the material. It is necessary to increase the quality of learning in order to better and complete student results through class action research by applying problem-based learning. This class action research aims to improve and complete the learning ability of students of study program of Chemical Education FKIP Riau University academic year 2011/2012 in the course of Basic Chemistry II. This study was conducted in three cycles. The increasing of mastery learning outcomes of students from the cycle I to Cycle II was $25 \%$ and from Cycle II to Cycle III was $54.17 \%$. Improving the ability of students to learn this by: 1) Teaching takes place in groups of 5 or 6 people. 2) Using instructional media in the form of textbooks, learning
\end{abstract}


materials and Student Work Sheet. 3) Lecturers encourage student to be active when group activities. 4) Lecturers provide guidance in groups and classical. 5) Time for classical discussion was long.

Keywords : Basic Chemistry II, Problem-based learning, Mastery learning outcomes.

\section{PENDAHULUAN}

Pembelajaran merupakan proses serangkaian hubungan timbal balik antara siswa dan guru untuk mencapai tujuan. Keberhasilan pembelajaran ditentukan oleh kemampuan pendidik dalam mengelola belajar (Suryosubroto, 2002). Suatu cara yang dapat dilakukan guru untuk mengoptimalkan hasil belajar adalah menerapkan metode pembejaran yang tepat (Slameto, 2003). Suatu faktor untuk mencapai tujuan pembelajaran adalah menekankan keterlibatan siswa (Dimyati dan Mudjiono 2002). Pembelajaran yang efektif yaitu proses belajar mengajar yang menyediakan kesempatan belajar sendiri atau melakukan aktivitas sendiri oleh siswa (Hamalik 2007). Dalam pembelajaran, guru mendorong, membimbing dan memberi fasilitas belajar. Pembelajaran berhasil apabila daya serap materi pengajaran mencapai prestasi tinggi, (Djamarah, 2002). Prestasi belajar maksimal yang dicapai dalam suatu usaha yang menghasilkan pengetahuan atau kecakapan (Yasa, 2008).

Proses pengajaran kimia dapat menggunakan berbagai metode pembelajaran dengan syarat metode yang digunakan sesuai dengan materi yang diajarkan. Kimia Dasar II merupakan dasar dari mata kuliah Kimia selanjutnya. Kimia Dasar II merupakan pengulangan dan pengembangan dari kimia sekolah menengah. Oleh sebab itu diharapkan hasil belajar mahasiswa pada kategori tinggi dan tuntas. Berdasarkan pendapat dan penjelasan diharapkan aktifitas siswa tinggi, hasil belajar siswa baik dan tuntas. Tetapi kenyataan di lapangan adanya kecendrungan mahasiswa mengandalkan informasi dari dosen dan hasil belajar mahasiswa rendah, khusus Kimia Dasar II di Prodi Pendidikan Kimia FKIP UR tahun ajaran 2011/2012.

Hasil observasi dan wawancara dengan mahasiswa, ternyata sebagian besar mahasiswa sulit untuk memahami materi dan berdampak terhadap hasil belajar. Untuk itu perlu dilakukan usaha peningkatan kualitas pembelajaran agar hasil belajar yang tuntas. Dalam usaha menuntaskan hasil belajar mahasiswa, dosen perlu melakukan perbaikan pembelajaran dengan mengunakan metode yang tepat dan bervariasi sehingga 
proses pembelajaran menjadi efektif. Penelitian ini menerapkan pembelajaran berdasarkan masalah untuk menuntaskan hasil belajar mahasiswa.

Kegiatan belajar dikatakan berhasil apabila mencapai tingkat ketuntasan (Suryosubroto, 2002). Ketuntasan belajar adalah pencapaian penguasaan minimal yang ditetapkan untuk setiap unit bahan pelajaran baik secara perorangan maupun secara kelompok. Faktor-faktor yang mempengaruhi penguasaan penuh antara lain bakat untuk menguasai sesuatu, mutu pelajaran, kemampuan untuk menerima pelajaran, ketekunan serta kesempatan yang tersedia untuk belajar (Slameto 2003).

Untuk menentukan tuntas pelaksanaan proses belajar mengajar didasarkan atas penguasaan minimal materi pelajaran oleh siswa. Departemen pendidikan dan kebudayaan (2001) menuangkan konsep belajar tuntas diantaranya, ketuntasaan belajar merupakan pencapaian taraf penguasaan minimal yang ditetapkan bagi setiap unit bahan ajar, baik secara individu, maupun kelompok. Pembelajaran berdasarkan masalah pembelajaran yang menghubungkan informasi dengan konsep yang telah dimiliki siswa. Pembelajaran berdasarkan masalah merupakan pendekatan pembelajaran pada masalah autentik untuk mencari penyelesaian (Arends, 1997).

Belajar adalah kegiatan yang disengaja, ditandai dengan perubahan tingkah laku sebagai interaksi dengan lingkungan (Hamalik, 2007). Belajar merupakan proses yang berlangsung dalam diri seseorang yang mengubah tingkah lakunya, dalam berpikir, bersikap, maupun berbuat (Gulo 2002). Belajar suatu proses dilakukan untuk memperoleh perubahan tingkah laku, sebagai hasil pengalaman sendiri dalam interaksi dengan lingkungan. Belajar efektif tercapai bila mengunakan strategi yang tepat untuk mencapai hasil maksimal (Slameto, 2003). Belajar suatu proses yang ditandai adanya perubahan positif, misalnya perubahan pengetahuan, pemahaman, keterampilan, dan aspek lainnya (Sudjana 2005). Perubah tingkah laku melalui pengalaman diperoleh dengan melihat, mengamati, dan memahami (Djamarah dan Zain (2006). Belajar merupakan proses aktif merangkai pengalaman, menggunakan masalah nyata dilingkungan untuk berlatih (Ibrahim, 2005).

Pembelajaran adalah kombinasi yang tersusun meliputi manusiawi, material, fasilitas, perlengkapan, dan prosedur yang saling mempengaruhi mencapai tujuan pembelajaran (Hamalik, 2007). Pembelajaran membangun pengalaman belajar dengan berbagai keterampilan proses sehingga mendapatkan pengalaman baru (Zainon, 2007). 
Pembelajaran merupakan proses interaksi peserta didik dengan pendidik dan sumber belajar pada suatu lingkungan belajar (Krismanto, 2003).

Kegiatan pembelajaran memberikan pengalaman belajar yang berguna dan menyenangkan, dosen hendaknya kreatif menciptakan pembelajaran menyenangkan bagi mahasiswa, menyesuaikan dengan kemampuan dan karakteristik siswa (Neviyarni, 2005). Pembelajaran merupakan suatu proses yang mengandung serangkaian perbuatan guru dan siswa, yang berlangsung dalam situasi edukatif (Usman, 2004). Pembelajaran merupakan proses interaksi peserta didik dengan pendidik dan sumber belajar pada suatu lingkungan belajar (Krismanto, 2003).

Model pembelajaran merupakan kerangka konseptual yang melukiskan prosedur sistematis dalam mengorganisasikan pengalaman belajar untuk mencapai tujuan (Suprijono, 2009). Strategi pembelajaran berdasarkan masalah merupakan rangkaian aktivitas pembelajaran yang menekankan kepada proses penyelesaikan masalah secara ilmiah. Ciri pembelajaran berdasarkan masalah yaitu, mempunyai sejumlah kegiatan, pembelajaran diarahkan untuk menyelesaikan masalah, dan pendekatan pemecahan masalah menggunakan pendekatan ilmiah (Sanjaya, 2008).

Kelebihan pembelajaran berdasarkan masalah, 1) Siswa dilibatkan pada kegiatan belajar, 2) siswa dilatih untuk dapat bekerja sama, dan 3) memperoleh pelajran dari berbagai sumber (Kiranawati, 2007). Secara umum tahapan pembelajaran, yaitu kegiatan awal, kegiatan inti dan kegiatan akhir. Kegiatan awal bertujuan membangkitkan motivasi intrinsik, dan mengorientasikan siswa kepada masalah. Kegiatan inti dimulai dengan merumuskan masalah. Tahap selanjutnya siswa secara kelompok menjawab masalah melalui pengamatan dan eksperimen kemudian menyimpulkan. Kegiatan inti, guru membimbing mengembangkan hasil karya siswa. Kegiatan akhir merupakan kegiatan pemantapan. Peran pendidik, 1) mengarahkan pada masalah, 2) /membimbing penyelidikan, 3) memfasilitasi dan memotivasi, dan 4) mendukung belajar siswa. (Ibrahim dan Nur, 2000).

\section{METODE PENELITIAN}

Penelitian tindakan kelas ini dilaksanakan di Program studi Kimia FKIP Universitas Riau. Waktu penelitian pada semester genap tahun ajaran 2011/2012. Subjek penelitian mahasiswa semester 2 Program Studi Pendidikan Kimia. 
Parameter yang diamati; 1) Hasil belajar mahasiswa yang berupa ketuntasan belajar secara individu dan klasikal pada setiap siklus. 2) Aktivitas mahasiswa dalam proses pembelajaran mengunakan lembaran obsevasi. 3) Aktivitas dosen dalam proses perkuliahan mengunakan lembaran obsevasi

Instrumen dalam penelitian ada dua yaitu; perangkat pembelajaran (Silabus mata kuliah Kimia Dasar II dan Satuan Acara Perkuliahan, Lembaran Kerja Mahasiswa) dan instrumen pengumpul data yaitu evaluasi hasil belajar berupa tes, dan lembaran aktivitas mahasiswa dan dosen untuk setiap pertemuan.

Penelitian dilaksanakan tiga siklus, dan setiap siklus terdiri atas dua kali pertemuan. Pokok Bahasan yang dipilih yaitu Sel Galvani, Elektrolisis dan Koloid. Prosedur penelitian setiap siklus meliputi perencanaan, pelaksanaan, observasi dan refleksi.

Data penelitian dikumpulkan dengan observasi dan melalui tes tertulis untuk setiap siklus. Data observasi digunakan untuk melihat aktivitas mahasiswa dan dosen dalam proses belajar. Data hasil belajar, digunakan untuk refleksi perbaikan pembelajaran siklus berikutnya dan untuk melihat peningkatan hasil belajar.

Penguasaan materi mengacu kepada ketuntasan belajar individual dan klasikal. Ketuntasan individu ditetapkan nilai 65, dan klasikal 75\%. Peningkatan hasil belajar dilihat dari Siklus I dan II, dan dari Siklus II dengan Siklus III. Aktivitas dosen dan perangkat pembelajaran dilihat setiap pembelajaran.

\section{HASIL DAN PEMBAHASAN}

\section{Hasil}

\section{Hasil Tindakan Siklus I}

Nilai hasil belajar mahasiswa pada Siklus I diperoleh nilai tertinggi 82,5 dan nilai terendah 0,0. Analisis nilai hasil belajar dapat dilihat pada Tabel 1.

Tabel 1 Nilai Hasil Belajar dan Frekwensi Mahasiswa Pada Siklus I

\begin{tabular}{ccccc}
\hline $\begin{array}{l}\text { Kriteria } \\
\text { Penilaian }\end{array}$ & Nilai & Frekwensi & $\%$ & Keterangan \\
\hline$>84$ & A & 0 & 0,00 & Tuntas \\
\hline $75-84$ & B & 7 & 14,58 & Tuntas \\
\hline $65-74$ & C & 2 & 4,17 & Tuntas \\
\hline $55-64$ & D & 8 & 16,67 & Belum tuntas \\
\hline$<55$ & E & 31 & 64,58 & Belum tuntas \\
\hline
\end{tabular}


Ketuntasan belajar secara individu dan klasikal Siklus I dapat dilihat pada Tabel 2.

Tabel 2 Ketuntasan Belajar Mahasiswa Pada Siklus I

\begin{tabular}{llcc}
\hline No. & Kategori & Jumlah & $\%$ \\
\hline 1 & Individu yang tuntas & 9 Orang & 18,75 \\
\hline 2 & Individu yang tidak tuntas & 39 orang & 81,25 \\
\hline & Jumlah & 48 orang & 100,00 \\
\hline
\end{tabular}

Hasil observasi pada Siklus I dirangkum pada Tabel 3.

Tabel 3. Pembagian Waktu Aktivitas Pembelajaran Pada Siklus I

\begin{tabular}{|c|c|c|c|c|}
\hline \multirow[t]{2}{*}{ No } & \multirow[t]{2}{*}{ Aktivitas Pembelajaran } & \multicolumn{2}{|c|}{ Waktu (menit) } & \multirow{2}{*}{$\begin{array}{c}\% \\
\text { waktu }\end{array}$} \\
\hline & & Pertemuan 1 & Pertemuan 2 & \\
\hline 1. & Kegiatan Awal Pembelajaran & 15 & 15 & 10 \\
\hline \multirow[t]{4}{*}{2.} & Kegiatan Inti Pembelajaran & & & \\
\hline & 1. Penjelasan materi oleh dosen & 15 & 15 & 10 \\
\hline & 2. Diskusi Kelompok & 90 & 90 & 60 \\
\hline & 3. Diskusi belajar secara klasikal & 15 & 15 & 10 \\
\hline 3. & Kegiatan Penutup & 15 & 15 & 10 \\
\hline & Jumlah & 150 & 150 & 100 \\
\hline
\end{tabular}

Masalah pada pokok bahasan Sel Galvani: 1) Mengapa sel aki dapat menghasilkan arus lestrik, 2) Mengapa untuk menghidari perkaratan besi dilapisi dengan seng.

Aktivitas belajar yang diamati adalah; Pertama aktivitas dosen yaitu 1) Mengarahkan mahasiswa secara klasikal, 2) Mengajukan pertanyaan pada setiap kelompok, 3) Membantu kelompok mengerjakan LKM, 4) Mengajukan pertanyaan pada klasikal, dan 5) Merangkum materi bersama mahasiswa. Kedua aktivitas mahasiswa; 1) Mahasiswa sebagian kecil yang aktif, 2) Sebagian kecil mahasiswa yang merespon pertanyaan, 3) Respon mahasiswa kurang tepat, 4) Mahasiswa kurang memahami permasalahan, dan 5) Sebagian besar mahasiswa belum membuat laporan sesuai permasalahan. Ketiga media yang digunakan; sebagian besar mahasiswa tidak mempunyai bahan rujukan. Media pembelajaran berupa LKM.

Hasil Siklus I ketuntasan belum tercapai dan kualitas pembelajaran masih rendah serta proses pembelajaran belum mencermin pembelajaran berdasarkan masalah. Untuk pembelajaran berikutnya pembelajaran ini perlu diperbaiki.

Faktor penyebab tidak tuntasnya hasil belajar mahsiswa, dilihati; Pertama aktifitas mahasiswa yaitu; 1) Mahasiswa sebagian kecil aktif diskusi kelompok, 2) Sebagian kecil mahasiswa yang merespon pertanyaan dosen, 3) Respon mahasiswa 
kurang tepat dan 4) Mahasiswa kurang memahami permasalahan, 5) Sebagian kecil mahasiswa membuat laporan sesuai dengan tugas yang diberikan. Kedua sarana pembelajaran; 1) Sebagian besar mahasiswa tidak mempunyai rujukan. 2) Tuntutan dalam LKM sebagaian dari besar mahasiswa belum dapat mengerjakannya. Ketiga, waktu yang digunakan untuk diskusi kelompok belajar relatif lama, dan waktu penjelasan oleh dosen relatif singkat. Oleh sebab proses pembelajaran yang dilaksanakan berdasarkan masalah perlu diperbaiki pada Siklus II.

Perbaikan proses pembelajaran pada Siklus II direncanakan: 1) pembelajaran dilaksanakan diskusi kelompok dan memperdayakan tingkat keaktifan mahasiswa yang lebih tinggi. 2) aktivitas dosen dalam pembelajaran (1) mengarahkan mahasiswa secara klasikal, (2) mengajukan pertanyaan pada setiap kelompok, (3) membantu kelompok mengerjakan LKM, (4) mengajukan pertanyaan pada setiap kelompok dan (5) merangkum materi bersama mahasiswa dan dosen. 3) disarankan mahasiswa memiliki bahan bacaan yang sesuai dengan masalah.4) Pembagian waktu untuk aktivitas pembelajaran untuk tiap kali pertemuan (1) Persiapan pembelajaran 15 menit, (2) Penjelasan materi secara umum dosen 15 menit, (3) Diskusi kelompok 60 menit, (4) Diskusi belajar secara klasikal 45 menit. Kegiatan penutup 15 menit.

\section{Hasil Tindakan Siklus II}

Hasil belajar pada Siklus II dengan materi Elektrolisis nilai tertinggi 96 dan terendah 42. Analisis data hasil belajar pokok bahasan Elektrolisis pada Tabel 4.

Tabel 4. Nilai Hasil Belajar dan Frekwensi Mahasiswa Pada Siklus II

\begin{tabular}{cccrc}
\hline Kriteria Penilaian & Nilai & Frekwensi & $\%$ & Keterangan \\
\hline$>84$ & A & 5 & 10,42 & Tuntas \\
\hline $75-84$ & B & 4 & 8,33 & Tuntas \\
\hline $65-74$ & C & 12 & 25,00 & Tuntas \\
\hline $55-64$ & D & 12 & 25.00 & Belum tuntas \\
\hline$<55$ & E & 15 & 31,25 & Belum tuntas \\
\hline
\end{tabular}

Ketuntasan belajar secara individu dan klasikal Siklus II dapat dilihat pada Tabel 5. Tabel 5. Ketuntasan Belajar Mahasiswa Pada Siklus II

\begin{tabular}{llcc}
\hline No. & Kategori & Jumlah & $\%$ \\
\hline 1 & Individu yang tuntas & 21 Orang & 43,75 \\
\hline 2 & $\begin{array}{l}\text { Individu yang tidak } \\
\text { tuntas }\end{array}$ & 27 orang & 56,25 \\
\hline \multicolumn{2}{c}{ Jumlah } & 48 orang & 100,00 \\
\hline
\end{tabular}


Hasil observasi yang diamati pembelajaran Siklus II dirangkum pada Tabel 6.

Tabel 6 Pembagian Waktu Aktivitas Pembelajaran Pada Siklus II

\begin{tabular}{|c|c|c|c|c|}
\hline \multirow[t]{2}{*}{ No } & \multirow[t]{2}{*}{ Aktivitas Pembelajaran } & \multicolumn{2}{|c|}{ Waktu (menit) } & \multirow{2}{*}{$\begin{array}{c}\% \\
\text { waktu }\end{array}$} \\
\hline & & Pertemuan 1 & Pertemuan 2 & \\
\hline 1. & Kegiatan Awal Pembelajaran & 15 & 15 & 10 \\
\hline \multirow[t]{4}{*}{2.} & Kgiatan Inti Pembelajaran & & & \\
\hline & 1. Penjelasan materi oleh dosen & 15 & 15 & 10 \\
\hline & 2. Diskusi Kelompok & 60 & 60 & 40 \\
\hline & 3. Diskusi belajar secara klasikal & 45 & 45 & 30 \\
\hline 3. & Kegiatan Penutup & 15 & 15 & 10 \\
\hline & Jumlah & 150 & 150 & 150 \\
\hline
\end{tabular}

Masalah yang diajukan pada pokok bahasan Elektrolisis yaitu: 1) Mengapa elektrolisis larutan garam $(\mathrm{NaCl})$ dihasil gas oksigen dan hidrogen. 2) Mengapa pada proses pelapisan besi dengan nikel, besi sebagai katoda dan nikel sebagai anoda?

Selama proses pengajaran Siklus II aktivitas yang diamati adalah; Pertama aktivitas dosen; 1) Mengarahkan mahasiswa secara klasikal, 2) Mengajukan pertanyaan pada setiap kelompok, 3) Membantu kelompok mengerjakan LKM, 4) Mengajukan pertanyaan pada diskusi klasikal, dan 5) Merangkum materi. Kedua aktivitas mahasiswa; 1) Mahasiswa sebagian aktif diskusi kelompok, 2) Sebagian mahasiswa merespon pertanyaan dosen, 3) Respon mahasiswa belum tepat, 4) Mahasiswa belum memahami permasalahan. 5) Sebagian mahasiswa belum membuat laporan sesuai dengan tujuan. Ketiga; sebagian mahasiswa tidak mempunyai bahan rujukan dan media pembelajaran berupa LKM.

Hasil Siklus II ketuntasan belajar belum tercapai, kualitas pembelajaran masih rendah dan proses pembelajaran belum mencermin pembelajaran berdasarkan masalah. Untuk pembelajaran berikutnya pembelajaran ini perlu diperbaiki.

Faktor penyebab masih rendahnya hasil belajar mahasiswa, dilihat dari aspek dosen 1) belum semua mahasiswa memahami pengarahan dosen, 2) kebanyakan kelompok kurang mengerti dari pertanyaan dosen. 3) sebagian mahasiswa tidak memahami materi pelajaran. 4) mahasiswa belum bisa menjawab pertanyaan dosen dengan tepat. 5) dosen rangkuman materi pelajaran belum mencapai tujuan.

Dilihat dari aktifitas mahasiswa; 1) Mahasiswa sebagian yang aktif waktu diskusi kelompok, 2) Sebagian mahasiswa yang merespon pertanyaan dosen, 3) Respon mahasiswa belum tepat dan 4) Mahasiswa belum memahami permasalahan yang diajukan dosen, 5) Hasil laporan mahasiswa belum mencapai standar. 
Dari aspek sarana pembelajaran; 1) Sebagian mahasiswa tidak mempunyai bahan rujukan. 2) LKM menutut setiap mahasiswa belajar untuk; 1) merumuskan hipotesis berdasarkan masalah yang telah dirumuskan, 2) membahas masalah berdasarkan hipotesis yang dirumuskan oleh kelompok mahasiswa, 3) menjawab pertanyaan yang diajukan, dan 4) membuat kesimpulan, sama dengan pada Siklus I.

Dari aspek waktu yang digunakan diskusi kelompok belajar kurang dari pada Siklus I, dan waktu penjelasan oleh dosen relatif lebih lama. Dosen dapat menjelaskan materi pelajaran secara terperinci dan tuntas.

Perbaikan pembelajaran Siklus III, Pokok bahasan Koloid, dilaksanakan dua kali pertemuan. Perbaikan pembelajaran Siklus III, direncanakan: Pertama, pada Siklus II pembelajaran dengan diskusi kelompok, tetapi belum semua mahasiswa aktif, dan merasa bertanggung. Berdasarkan hal ini maka untuk Siklus III pembelajaran dilaksanakan secara diskusi kelompok lebih memperdayakan keaktifan mahasiswa. Kedua, pembahasan dosen belum sisematis dan rangkuman materi belum mencapai tujuan, Untuk Siklus III aktivitas dosen direncanakan; 1) mengarahkan mahasiswa secara klasikal, 2) mengajukan pertanyaan pada setiap kelompok, 3) membantu kelompok mengerjakan LKM, 4) mengajukan pertanyaan secara klasikal dan 5) merangkum materi bersama mahasiswa. Ketiga, tidak semua mahasiswa memiliki bahan bacaan. Untuk siklus III disarankan mahasiswa memiliki bahan bacaan. LKM menutut mahasiswa untuk; 1) merumuskan hipotesis, 2) membahas masalah, 3) menjawab pertanyaan, dan 4) membuat kesimpulan. Keempat, pembagian waktu aktivitas pembelajaran. Rencana penggunaan waktu Siskus III adalah: 1) Persiapan pembelajaran 15 menit, 2) Penjelasan materi secara umum 15 menit, 3) Diskusi kelompok selama 45 menit, 4) Diskusi klasikal selama 60 menit. Kegiatan penutup 15 menit.

Dengan merencanakan strategi pembelajar kelompok, keterlibatan dan aktivitas dosen, penggunaan media dan pembagian waktu yang telah direncanakan, diharapkan ketuntasan belajar mahasiswa Siklus III meningkat dari pada Siklus II.

\section{Hasil Belajar Tindakan Siklus III}

Nilai hasil belajar mahasiswa Siklus III dengan materi Koloid,nilai tertinggi 90 dan nilai terendah 61. Analisis data hasil belajar ini dirangkum pada Tabel 7. Masalah Siklus III: 1) Mengapa waktu kabut, kendaraan memasang lampu kuning? 2) Mengapa pada pembuatan tahu digunakan cairan yang bersifat asam? 3) Mengapa terjadi delta 
pada pertemuan sungai dengan laut? 4) Mengapa silikagel dapat digunakan sebagai pengering?

Aktivitas yang diamati; Pertama, aktivitas dosen; 1) Mengarahkan mahasiswa secara klasikal, 2) Mengajukan pertanyaan pada setiap kelompok, (3) Membantu kelompok mengerjakan LKM, 4) Mengajukan pertanyaan secara klasikal, dan 5) Merangkum materi bersama mahasiswa. Kedua aktivitas mahasiswa adalah; 1) Mahasiswa sebagian besar aktif dalam diskusi kelompok, 2) Sebagian besar mahasiswa merespon pertanyaan dosen, 3) Respon mahasiswa tepat. 4) Mahasiswa memahami permasalahan. 5) Sebagian mahasiswa membuat laporan sesuai dengan permasalahan. Ketiga; Semua mahasiswa mempunyai; 1) bahan rujukan dan 2) media berupa LKM.

Tabel 7 Nilai Hasil Belajar dan Frekwensi Mahasiswa Pada Siklus III

\begin{tabular}{ccccc}
\hline Kriteria Penilaian & Nilai & Frekwensi & $\%$ & Keterangan \\
\hline$>84$ & A & 6 & 12,50 & Tuntas \\
\hline $75-84$ & B & 35 & 72,92 & Tuntas \\
\hline $65-74$ & C & 6 & 12,50 & Tuntas \\
\hline $55-64$ & D & 1 & 2,08 & Belum tuntas \\
\hline$<55$ & E & 0 & 00,00 & Belum tuntas \\
\hline
\end{tabular}

Hasil belajar mahasiswa secara individu dan klasikal Siklus III dilihat pada Tabel 8.

Tabel 8. Ketuntasan Belajar Mahasiswa Pada Siklus III

\begin{tabular}{llcc}
\hline No. & Kategori & Jumlah & $\%$ \\
\hline 1 & Individu yang tuntas & 47 Orang & 97,92 \\
\hline 2 & Individu yang tidak tuntas & 1 orang & 2,08 \\
\hline & Jumlah & 48 orang & 100 \\
\hline
\end{tabular}

Hasil observasi proses pembelajaran Siklus III dirangkum pada Tabel 9.

Tabel 9. Pembagian Waktu Aktivitas Pembelajaran Pada Siklus III

\begin{tabular}{llccc}
\hline No & \multicolumn{1}{c}{ Aktivitas Pembelajaran } & \multicolumn{2}{c}{ Waktu (menit) } & \multirow{2}{*}{$\%$} \\
\cline { 3 - 4 } & & Pertemuan 1 & Pertemuan 2 & waktu \\
\hline 1. & Kegiatan Awal Pembelajaran & 15 & 15 & 10 \\
\hline 2. & Kgiatan Inti Pembelajaran & & & \\
\cline { 2 - 4 } & 1. Penjelasan materi oleh dosen & 15 & 15 & 10 \\
\cline { 2 - 4 } & 2. Diskusi Kelompok & 45 & 45 & 30 \\
\cline { 2 - 4 } & 3. Diskusi belajar secara klasikal & 60 & 60 & 40 \\
\hline 3. & Kegiatan Penutup & 15 & 15 & 10 \\
\hline & $\quad$ Jumlah & 150 & 150 & 150 \\
\hline
\end{tabular}

Pada Siklus III ketuntasan belajar telah tercapai, dan kualitas pembelajaran yang baik Faktor yang menyebabkan hasil belajar mahasiswa sudah tuntas; 1) Waktu 
pengarahan mahasiswa secara klasikal, mahasiswa dapat memahaminya. Waktu mengajukan pertanyaan pada kelompok, respon dari setiap kelompok tidak sama, dan kebanyakan kelompok kurang mengerti. Waktu dosen membantu kelompok mengerjakan LKM sebagian mahasiswa tidak memahami materi. Waktu dosen mengajukan pertanyaan, jawaban mahasiswa belum tepat. Waktu dosen merangkuman materi pelajaran belum mencapai tujuan pembelajaran.

Dilihat dari aktifitas mahasiswa; 1) Mahasiswa sebagian besar aktif, 2) Sebagian besar mahasiswa merespon pertanyaan dosen, 3) Respon mahasiswa tepat 4) Mahasiswa memahami permasalahan yang diajukan, 5) Setiap mahasiswa membuat laporan, dan hasil laporan telah mencapai standar yang diinginkan.

Dari aspek sarana pembelajaran; 1) Sebagian besar mahasiswa mempunyai bahan rujukan. 2) LKM menutut mahasiswa untuk; (1) merumuskan hipotesis, (2) membahas masalah, 3) menjawab pertanyaan, dan 4) membuat kesimpulan. Waktu diskusi kelompok kurang dari Siklus II, dan waktu penjelasan dosen lebih lama.

\section{Pembahasan}

Hasil belajar Siklus I, 9 orang tuntasan dan ketuntasan klasikal 18,75\%. Ketidak tuntasan belajar disebabkan: 1) Proses pembelajaran Siklus I, mahasiswa banyak yang pasif. 2) Kegiatan diskusi kelompok relatif lama. 3) Mahasiswa tidak memiliki bahan bacaan. 4) Waktu merangkum materi relatif pendek.

Hasil belajar pada Siklus II, 21 orang mahasiswa tuntasan klasikal 43,75\%. Hal ini berarti bahwa tujuan pembelajaran belum tercapai. Ketidak tuntasan belajar pada Siklus II antara lain disebabkan: 1) kegiatan diskusi kelompook banyak mahasiswa yang tidak aktif. 2) dosen belum maksimal berinteraksi dengan kelompok mahasiswa. 3) waktu yang digunakan merangkum materi relatif sedikit.

Hasil belajar Siklus III, yang tuntas 47 orang, ketuntasan klasikal 97,92\%. Berarti tujuan pembelajaran sudah tuntas secara individu dan klasikal. Peningkatan ketuntasan belajar ini antara lain dipengeruhi: 1) pembelajaran dilaksanakan secara kelompok, sebagian besar mahasiswa aktif dalam diskusi kelompok. 2) Pembelajaran menggunakan alat bantu mengajar berupa LKM, bahan bacaan dan sumber lain. 3) Dosen mengarahkan pada diskusi kelompok dan diskusi klasikal. 


\section{KESIMPULAN DAN SARAN}

\section{Kesimpulan}

Kesimpulan hasil penelitian tindakan kelas pelajaran Kimia Dasar II ini adalahn: (1) Pada Siklus I individu yang tuntas 9 orang dan ketuntasan klasikal 18,75 \%, (2) Pada Siklus II individu yang tuntas 21 orang dan ketuntasan klasikal 43,75 \%, (3)Pada Siklus III individu yang tuntas 47 orang dan ketuntasan klasikal 97,92 \%, (4) Peningkatan ketuntasan dari Siklus I dengan Siklus II sebanyak $25 \%$, (5) Peningkatan ketuntasan belajar dari Siklus II dengan Siklus III 54,17 \%. Dari pengolahan dapat disimpulkan ketuntasan belajar tercapai pada Siklus III.

Pengajaran Kimia Dasar II yang dilaksanakan dengan model pembelajaran berdasarkan masalah dapat menuntaskan hasil belajar dan meningkatkam kemampuan belajar dengan cara: (1) Pengajaran dilaksakan secara kelompok yang terdiri dari 5 atau 6 orang, (2) Menggunakan media pembelajaran berupa buku bacaan dan bahan pembelajaran dan LKM, (3) Dosen mendorong keaktifan mahasiswa waktu kegiatan kelompok, (4) Dosen memberikan arahan, dan menjelaskan materi secara kelompok dan secara klasikal, (5) Waktu untuk diskusi secara kelompok dibutuhan waktu relatif pendek, (6) Diskusi klasikal dibutuhan waktu yang relatif lama, (6) Pengarahkan dosen sesuai dengan permasalahan.

\section{Saran}

Berdasarkan temuan penelitian tidakan kelas ini disarankan dalam proses pembelajaran dosen perlu; (1) Memberikan dorongan kepada mahasiswa untuk aktif, (2) Memberikan arahan materi pelajaran sesuai permasalahan, (3) Meningkatkan keaktifkan mahasiswa. (4) Membimbing mahasiswa pada waktu diskusi kelompok untuk memecahkan permasalahan yang diajukan, (5) Mengarahkan mahasiswa pada waktu diskusi secara klasikal dan mahasiswa harus memiliki buku bacaan. (6) Mahasiswa harus mencari informasi sesuai dengan masalah.

\section{DAFTAR PUSTAKA}

Arends, R, 1997, Classroom Instruction and Management, New York Mc Grow Hill Compagnies

Dimyati dan Mudjiono, 2002, Belajar dan Pembelajaran, Rineka Cipta, Jakarta.

Djamarah, B.S dan Zein, Aswan. 2002, Strategi Belajar Mengajar, Rineka Cipta, Jakarta.

Hamalik. Oemar, 2007, Kurikulum dan Pembelajaran, Bumi Aksara, Jakarta. 
Ibrahim, Muslimin dan Muhammad Nur, 2005, Pembelajaran Berdasarkan Masalah, Universiti Press. Surabaya.

Gulo, W., 2002, Strategi Belajar Mengajar, Gramedia, Jakarta.

Kiranawati, 2007, Pembelajaran Berdasarkan Masalah http://gurupkn. wordpress.com. (6-1-2009).

Krismanto, 2003, Pengertian dan Ciri-ciri Pembelajaran, http://kris.1.blog.uns.ac.id/pengertian-dan-ciri-ciri-pembelajaran/ (15-8-2011).

Neviyarni, 2005, Strategi Pembelajaran, Pustekom, Diknas, Pekanbaru.

Sanjaya. Wina, 2008, Strategi Pembelajaran, Kencana, Jakarta

Slameto, 2003, Belajar dan Faktor-faktor Yang Mempengaruhinya, Rineka Cipta, Jakarta

Sudjana, N., 2005, Dasar-dasar Proses Belajar Mengajar, Sinar Baru Muda Algensindo, Bandung.

Suprijono, A., 2009, Cooperatif Learning Teori Aplikasi Paikem, Pustaka Pelajar, Yogyakarta.

Suryosubroto, B., 2002, Proses Belajar Mengajar di Sekolah, Rineka Cipta, Jakarta.

Usman, U., 2004, Menjadi Guru Profesional, Remaja Rosda Karya, Bandung.

Yana,D., 2008, Aktivitas dan Prestasi Belajar,www.ipotesis.wordpress.com(6-6-09)

Zainon, 2007, Pembelajaran yang Aktif dan Menyenangkan. http://www.id.shvoog.com/pengertian-pembelajaran-aktif.html. (8 -8- 2011) 